\title{
Alexander disease type II
}

INSERM

\section{Source}

INSERM. (1999). Orphanet: an online rare disease and orphan drug data base. Alexander disease type II. ORPHA:363722

Alexander disease type II (AxD type II) is an astrogliopathy and a form of Alexander disease (AxD; see this term) characterized by ataxia, bulbar symptoms, spastic paraparesis, palatal myoclonus, and autonomic symptoms. 